\title{
Decolourisation of Textile Wastewater by Dye Degrading Microorganisms Isolated from Textile Effluent
}

\author{
Ahenkan Serwaa Afena1 ${ }^{*}$, Derrick Kontoh Boateng'2, Lawrence Darkwah³, Albert A. Adjaottor ${ }^{1}$ \\ ${ }^{1}$ Department of Materials Engineering, Kwame Nkrumah University of Science and Technology, Kumasi, Ghana \\ ${ }^{2}$ Department of Pharmaceutics, Kwame Nkrumah University of Science and Technology, Kumasi, Ghana \\ ${ }^{3}$ Department of Chemical Engineering, Kwame Nkrumah University of Science and Technology, Kumasi, Ghana \\ Email: *afenaboadum@gmail.com
}

How to cite this paper: Afena, A.S., Boateng, D.K., Darkwah, L. and Adjaottor, A.A. (2021) Decolourisation of Textile Wastewater by Dye Degrading Microorganisms Isolated from Textile Effluent. Journal of Environmental Protection, 12, 767-783. https://doi.org/10.4236/jep.2021.1210046

Received: May 11, 2021

Accepted: October 25, 2021

Published: October 28, 2021

Copyright (c) 2021 by author(s) and Scientific Research Publishing Inc. This work is licensed under the Creative Commons Attribution International License (CC BY 4.0).

http://creativecommons.org/licenses/by/4.0/

\begin{abstract}
Dyes mostly used in the textile industry end up in their wastewater. The treatment of textile effluent has become necessary because of its associated environmental and health problems. In this study, five bacterial isolates were obtained from textile effluent. The isolated bacteria were used to decolourise effluent samples in a time-dependent manner and the change in colour was observed using an Ultraviolet-visible spectrophotometer. After 24 hours, decolourisation efficiencies of the five isolates were calculated and the highest decolourisation efficiency (78.5\%) was observed with one of the isolates (E12). Isolate E23 recorded 64.7\% followed by isolate E9 (62.0\%) and E21 (53.7\%). Isolate E19 had the lowest decolourisation efficiency (2.6\%). The isolated bacteria were identified with E9 as Aeromonas hydrophilia, E12 as Aeromonas hydrophilia, E19 as Pseudomonas aeruginosa, E21 as Aeromonas hydrophilia and E23 as Pseudomonas fluorescens. To achieve a decolourisation efficiency of $78.5 \%, 25 \mathrm{ml}$ of textile wastewater should be inoculated with $1 \mathrm{ml}$ of the isolate (E12) culture. Thus, Isolate E12 (Aeromonas hydrophilia) is considered a promising candidate for biological textile wastewater treatment followed by isolate E23 (Pseudomonas fluorescens).
\end{abstract}

\section{Keywords}

Textile, Effluent, Decolourisation, Bacteria

\section{Introduction}

Synthetic dyes are used extensively in the textile industries, most of which are readily soluble in water [1] [2] [3]. In most textile dyeing operations, as much as 
$15 \%$ of the dyes used do not connect to the fabrics, so they are lost to wastewater. The resulting effluent poses serious water pollution problems due to the colour content and accompanying toxic components. Problems associated with coloured textile effluent include the introduction of heavy metals into water bodies [4] [5], an increase in biochemical oxygen demand (BOD), chemical oxygen demand (COD), pH and suspended solids. Furthermore, the presence of synthetic dyes in wastewater makes the water smell unpleasantly, and aesthetically less pleasing as well as decreasing the amount of sunlight penetrating the water, thereby affecting photosynthesis and entire aquatic ecosystems [6] [7] [8]. Also, most of the dyes that are released into wastewater, including their breakdown products, are toxic, carcinogenic, mutagenic and teratogenic to humans and other life forms [2] [7] [9] [10] [11] [12] [13].

A textile company in Ghana produces and sells African fabrics both locally and internationally. The production of these fabrics involves the use of many synthetic dyes and high amounts of water, generating a lot of dye-wastewater. The company has a treatment plant that treats the wastewater in three different stages; biological treatment (use of microbes feeding on only the cellulosic materials in the effluent), ultrafiltration and Reverse Osmosis (RO). However, 70\% clear water is gained and recycled into the processing plant after final treatment by RO. The remaining 30\%, termed as concentrate or rejects, is stored because it still contains colour. This puts pressure on the storage unit sometimes leading to causing overflow. The company seeks to further treat this concentrate or reject to be reused for production in a sustainable way.

Several physico-chemical methods such as adsorption, electrocoagulation, flocculation, ion exchange, membrane filtration, ozonation, and reverse osmosis, have been used for the decolourisation of dye-containing wastewater [14] [15]. However, these methods are expensive and produce large amounts of sludge after treatment which requires safe disposal [16]. On the other hand, biological treatment methods are found to be more suitable and widely used presently, due to their cost-effectiveness, ability to produce less sludge, and its eco-friendly nature [2] [16]-[23].

In addition, most research is focused on the degradation or decolourisation of individual textile dyes [11] [21] [24] [25] [26] [27] [28]. However, information about dye wastewater decolourisation by microorganisms is limited.

This study, therefore, aimed to decolourise the concentrate (R.O. reject) that is currently stored at the company's premises using biological treatment methods. The specific objectives included: 1) isolation and screening of microorganisms from textile effluent; 2) identifying the isolated microorganisms; and 3) decolourising effluent samples using identified isolates.

\section{Materials and Methods}

\subsection{Sample Collection and Coding}

Effluent samples were collected from nine different locations (Table 1) within the plant using a bailer and sterile plastic bottles. The sampling protocol defined 
by [24] was followed with modification. The samples were placed in a cold (temperature of $0^{\circ} \mathrm{C}$ ) flask and transported to the laboratory for analysis.

\subsection{Physico-Chemical Parameters of Effluent Samples}

Physico-chemical parameters namely colour, $\mathrm{pH}$ and temperature of the effluent samples were recorded using visual inspection, $\mathrm{pH}$ meter and standard thermometer.

\subsection{Preliminary Screening of Samples to Isolate Microorganisms}

Heterotrophic microbes were isolated from the samples following a modified version of the protocol previously described by [29]. One millilitre (1 $\mathrm{ml})$ of the sample was diluted with $9 \mathrm{ml}$ of sterile water. The mixture was then diluted 1000 folds. One millilitre $(1 \mathrm{ml})$ of the final dilution of each sample was placed in a sterile petri-dish and $20 \mathrm{ml}$ of Muller Hinton Agar was added. The Muller Hinton Agar plates were incubated for 24 hours at $37^{\circ} \mathrm{C}$. Sub-culturing of the resulting microbial colonies was done by fishing out colonies into freshly prepared nutrient broth. The petri-dishes and nutrient broth tubes were appropriately labelled. The experiment was performed in triplicates for each sample.

\subsection{Qualitative Dye Utilisation and Zone of Dye Clearance Test}

To determine the dye degrading property of the isolates, the protocol as described by [29] was followed with some modification. An amount of Methyl Red $(0.2 \mathrm{ml})$ was spread on the surface of Muller Hinton Agar plates using a sterile glass rod. Sterile filter paper discs were dipped into the isolates and placed on the Muller Hinton agar plates and further incubated at $37^{\circ} \mathrm{C}$ for 24 hours. Discs with clear zones of inhibition were then selected for further tests. The experiment was performed in triplicates for each sample.

\subsection{Identification of Selected Isolates}

Dye degrading microorganisms were identified based on Morphological tests (e.g. shape, size, colour and pattern of growth) and Biochemical tests (e.g. Indole test, Catalase, Carbohydrate utilisation test, Citrate utilisation, $\mathrm{H}_{2} \mathrm{~S}$ production and utilisation of selective media). All biochemical tests were performed as described by [29] and [30].

\subsubsection{Morphological Characterisation}

Dye degrading microorganisms were identified based on Morphological test. The aim of this test was to characterise the isolates based on their form, size, colour, and growth pattern on an agar plate. The morphological characterisation protocol of [29] was followed with some modifications. For this experiment, $20 \mathrm{ml}$ Tryptic Soy Agar (TSA) was melted and stabilized at $45^{\circ} \mathrm{C}$ before pouring into sterile petri dishes. After allowing the agar to set, a loopful of the culture was deposited on the agar surface. The plates were then incubated for 72 hours at $37^{\circ} \mathrm{C}$, with constant observation. 
Table 1. Sample coding and Collection points.

\begin{tabular}{cc}
\hline Sample code & Place of collection \\
\hline S1 & Main pit \\
S2 & Converging point of pits 1 and 2 \\
S3 & Converging point of pits 4 and 5 \\
S4 & Bleaching pit \\
S5 & Converging point of pits 2 and 3 \\
S6 & VAT (converging point of all coloured wastewater before treatment) \\
S7 & R.O. Reject (after physical and chemical treatment) \\
S8 & Sludge \\
S9 & End of pipeline \\
\hline
\end{tabular}

\subsubsection{Biochemical Reactions}

\section{a) Indole test}

The indole test is used to determine the ability of bacteria to oxidize tryptophan to indole, pyrivic acid, and ammonia. Since the tryptophanase enzyme is present in certain bacteria, this form of conversion is possible. Sultana [24] defined the indole test protocol, which was followed with some modifications. The isolates were grown in sterile tryptone broth in test tubes for this test. The tubes were incubated for 24 hours at $37^{\circ} \mathrm{C}$. Using a sterile pipette, a few drops of Kovacs' reagent were applied to the culture broth after incubation. The presence of indole was indicated by the appearance of a red layer in the medium, while the absence was indicated by the appearance of a yellow layer.

b) Carbohydrate utilisation test

This test was performed to determine whether bacteria could use a variety of sugars. Bacteria may be classified into genera based on the type of sugar they use [31]. $0.5 \mathrm{~g}$ tryptic soy broth (TSB) was weighed and dissolved in $4 \mathrm{ml}$ sterile distilled water in a test tube. $0.2 \mathrm{ml}$ Phenol red was added. At a concentration of $0.5 \%$, the preferred carbohydrate (lactose, glucose, or sucrose) was applied to the tubes separately. To extract air bubbles, Durham tubes were inverted in the media. The tubes were sterilized in an autoclave at $115^{\circ} \mathrm{C}$ for 30 minutes, after which they were allowed to cool to $45^{\circ} \mathrm{C}$. Each isolate was then inoculated into the sterile fermentation broth and labeled accordingly. The tubes were subsequently incubated for another 24 hours at $37^{\circ} \mathrm{C}$. The outcomes were properly recorded.

c) Hydrogen Sulphide $\left(\mathrm{H}_{2} \mathrm{~S}\right)$ production test

The test was done to determine the ability of some bacteria to reduce sulphurcontaining compounds to sulphides. This helps in biochemically characterising such bacteria and predicting the genera they belong to. The protein enrichment media protocol as described by Boateng [29] was followed with some modification for this test. Two isolated suspension loops $(0.02 \mathrm{ml})$ were inoculated into $10 \mathrm{ml}$ of peptone water. Between the cotton wool plug and the tubing, lead ace- 
tate paper was inserted. At $37^{\circ} \mathrm{C}$, the tubes were incubated for two days with regular observations. A black colouration of the lead acetate paper indicated a positive test.

d) Citrate utilisation test

The citrate test was used to determine a microorganism's ability to use citrate as the sole carbon source and inorganic ammonium salts as the sole source of nitrogen for metabolic processes, resulting in alkalinity. The presence of citrase enzyme, which allows citrate to be hydrolyzed into oxaloacetic acid and acetic acid, is needed for its use. In this study, a modified version of citrate utilisation protocol defined by Marimuthu et al. [32] was followed. Using a straightened wire, the subcultured isolates were introduced into sterile Koser's Citrate medium. The test tubes were then inoculated and incubated at $37^{\circ} \mathrm{C}$ for 72 hours, with constant observation. A colour change of the medium from green to blue denoted citrate utilisation.

e) Catalase test

Catalase is an enzyme that converts hydrogen peroxide $\left(\mathrm{H}_{2} \mathrm{O}_{2}\right)$ to water and oxygen. Catalase is produced by most pathogens to protect themselves against hydrogen peroxide attacks [24]. The isolates were subcultured on agar slants for 24 hours at $37^{\circ} \mathrm{C}$. A loopful of cells from each agar slant was combined with 0.2 $\mathrm{ml}$ of $30 \%$ hydrogen peroxide on a clean microscopic slide. Bubble formation indicated the existence of the catalase enzyme within a time span of 5 seconds to 3 minutes. The majority of the bubbles produced are oxygen bubbles, which are expressed by the formula:

$$
2 \mathrm{H}_{2} \mathrm{O}_{2}+\text { catalase enzyme } \rightarrow 2 \mathrm{H}_{2} \mathrm{O}+\mathrm{O}_{2} .
$$

f) Utilisation of selective media by study isolates

The ability of microbes to grow on certain selective media can enable their easy characterization. This is due to the availability of nutrients that are only available to them during their development [33]. For this test, the isolation protocol defined by Boateng [29] was followed with some modifications. Pseudomonas isolation medium and coliform selective medium were used as selective media. About $13 \mathrm{~g}$ of each selective medium was weighed into a $500 \mathrm{ml}$ infusion bottle and re-suspended in $500 \mathrm{ml}$ distilled water. The preparation was sterilised at $115^{\circ} \mathrm{C}$ for 30 minutes and then stabilised at $45^{\circ} \mathrm{C}$ for 15 minutes. The solution was then transferred into labelled sterile petri dishes in $10 \mathrm{ml}$ portions. Two loopfuls of the isolates were dropped onto the agar plate in turns. The plates were incubated at $37^{\circ} \mathrm{C}$ for 24 hours.

\subsection{Gram Staining}

The isolate $(0.1 \mathrm{ml})$ was heat-fixed on a slide. Ammonium oxalate crystal violet solution was applied and washed off after 20 seconds with sterile water. Lugol's iodine solution was then added. After a period of 30 seconds, ethanol at a concentration of $95 \%$, was used to decolourise the isolate for a period of 5 seconds. It was then washed with sterile water. Safranin at a concentration of $0.5 \%$ was 
used to counterstain the isolate and was washed off with sterile water after 30 seconds. A drop of immersion oil was used to cover the smear to increase the aperture of the lower objective lens for better viewing. The slide was then viewed under the microscope for its reaction to Gram's stain. The appearance of purple colonies indicates the presence of gram-positive bacteria. Whereas the appearance of pink colonies indicates the presence of gram-negative bacteria.

\subsection{Analytical Profile Index (API) 20 E Test}

The API 20 E test is a well-established method for the identification of the gramnegative Enterobacteria. It is a standardised and miniaturized system containing 20 biochemical tests. It uses biochemical reagents in the identification of organisms up to the species level. For this test, the test protocol as described by Martinez-Urtaza et al. [34] was followed with some modification.

A large colony ( $2-3 \mathrm{~mm}$ diameter) of the isolate was inoculated in $1 \mathrm{ml}$ of $0.85 \%$ saline solution and thoroughly mixed to obtain a homogenous solution. Using a sterile pipette, each well of the strip was inoculated with the bacterial suspension. The strip was then incubated in its chamber at $37^{\circ} \mathrm{C}$ for 18 hours.

\subsection{Decolourisation of Samples}

To ascertain the effectiveness of the obtained isolates in decolourising dye wastewater, two of the samples (S6 and S7) obtained from the textile company under study were inoculated with the isolates.

\subsubsection{Decolourisation of Sample 6 (S6-VAT)}

One millilitre $(1 \mathrm{ml})$ of the isolate culture was added to $25 \mathrm{ml}$ of the sample and made up to a final volume of $50 \mathrm{ml}$ using nutrient broth. The resulting mixture was left to stand for 24 hours at $25^{\circ} \mathrm{C}$. The procedure was repeated at a temperature of $40^{\circ} \mathrm{C}$ for the sample. Change in colour was observed using High Performance Liquid Chromatography (HPLC) method. The $\mathrm{pH}$ changes were also observed and readings taken.

\subsubsection{Decolourisation of Sample 7 (S7-RO Reject)}

To determine the wavelength of maximum absorbance of the samples, the protocol as described by [35] was followed with some modification. Ten (10) $\mu \mathrm{L}$ of the dye wastewater was poured into a $10 \mathrm{ml}$ volumetric flask and then topped to the mark with deionised water. It was scanned in the range of $200-700 \mathrm{~nm}$ using the UV-vis spectrophotometer. For analysis, $1 \mathrm{ml}$ of isolate was added to 25 $\mathrm{ml}$ of sample and sterile nutrient broth was used to make up to a volume of 50 $\mathrm{ml}$. The mixture was left to stand for 12 hours at $25^{\circ} \mathrm{C}$. At 2 hourly intervals (for the 12 hours), $2.5 \mathrm{ml}$ aliquot of the culture was drawn into a $2.5 \mathrm{ml}$ Eppendorf tube and centrifuged at $14,000 \mathrm{rpm}$ for 10 minutes. The resulting mixture was pipetted into a labelled well on a micro-titre plate. The UV-vis spectrophotometer was used to measure the absorbance of the mixture at $251 \mathrm{~nm}$. The procedure was repeated at 24 hours and $\mathrm{pH}$ values were recorded. 


\section{Results and Discussion}

\subsection{Physico-chemical Parameters of Effluent Samples}

Effluent samples collected from the company had basic $\mathrm{pH}$ which can be attributed to the extreme use of chemicals containing species such as $\mathrm{CO}_{3}^{2-}, \mathrm{HCO}_{3}^{-}$ and $\mathrm{NaOH}$ during various production processes. The colour of the samples varied at the various sampling points which could be attributed to the residual dye concentration in the samples. Temperature of the samples ranged from $26^{\circ} \mathrm{C}$ to $28^{\circ} \mathrm{C}$. Results are presented in Table 2 .

\subsection{Isolation, Screening and Identification of Dye Decolourising Bacterial Isolates}

The pour plate technique was used in isolating the microorganisms. A total of 23 bacterial colonies were isolated from the preliminary screening in nutrient agar. The isolation of various microorganisms from the samples demonstrates the normal adaptation of microbes to persist among noxious dyes.

Qualitative dye utilisation and Zone of clearance tests were performed for the 23 selected isolates, using methyl red, methylene blue and crystal violet dyes. The isolates which showed an affinity for all three dyes were 10 in number out of the 23 isolates. The isolates obtained were isolate, E9, E11, E12, E13, E14, E19, E20, E21, E22 and E23. Figures 1-3 graphically represent the utilisation of methyl red, methylene blue and crystal violet respectively for growth. Isolates with zone of clearance $10 \mathrm{~mm}$ and above were considered decolourisers and selected for further analysis. Similar kind of screening process was reported by [19] [24].

Table 3 and Table 4 illustrate the results obtained as a result of the morphological and biochemical reactions exhibited by the isolates. Ten isolates (E9, E11, E12, E13, E14, E19, E20, E21, E22 and E23), were considered for this test. The morphological and biochemical characteristics of the isolates were comparable to the description of Aeromonas and Psuedomonas strains as reported by [36] [37] [38].

Table 2. Characteristics of samples collected from different locations at the textile company.

\begin{tabular}{cccccc}
\hline Sample ID & Collection Point & Sample State & Colour & pH & Temperature $\left({ }^{\circ} \mathrm{C}\right)$ \\
\hline Sample 1 & Main pit & Liquid & Dark Green & 9.23 & 26 \\
Sample 2 & Converging point of pits 1 and 2 & Liquid & Deep Red & 8.40 & 26 \\
Sample 3 & Converging point of pits 4 and 5 & Liquid & Blue & 7.91 & 28 \\
Sample 4 & Bleaching pit & Liquid & Light Yellow & 8.22 & 26 \\
Sample 5 & Converging point of pits 2 and 3 & Liquid & Blackish & 7.91 & 26 \\
Sample 6 & VAT (converging point of all coloured wastewater & Liquid & Dark Green & 8.25 & 28 \\
Sample 7 & before waste treatment) & Liquid & Dark blue & 9.12 & 27 \\
Sample 8 & RO Reject & Sludge & Dark brown & 7.84 & 28 \\
Sample 9 & Sludge & Liquid & Greenish & 8.71 & 27 \\
\hline
\end{tabular}


Table 3. Morphological and biochemical reactions of isolates.

\begin{tabular}{|c|c|c|c|c|c|c|}
\hline Isolates & Morphology & $\mathrm{H}_{2} \mathrm{~S}$ & GLU & LAC & SUC & MRVP \\
\hline E9 & Light yellow colonies, Gram negative rods & + & + & + & + & +- \\
\hline E11 & White colony clusters, greenish zones. Gram negative & + & + & + & + & -+ \\
\hline E12 & Cream colonies, branching strands and pale yellowish zones. Gram negative & - & + & + & + & +- \\
\hline E13 & Light yellow colonies. Gram negative & - & + & + & - & -- \\
\hline E19 & Cream colony clusters with greenish zones, Gram negative & - & + & + & + & -- \\
\hline E20 & Cream colony clusters. Gram negative & - & + & + & + & -- \\
\hline $\mathrm{E} 21$ & Bright yellow colony clusters, Gram negative & + & + & + & + & -- \\
\hline $\mathrm{E} 22$ & White colony clusters, greenish zones. Gram negative & + & + & + & + & -+ \\
\hline E23 & White circular clusters, greenish zones Gram negative rods & + & + & + & + & +- \\
\hline
\end{tabular}

Key: $\mathrm{H}_{2} \mathrm{~S}=$ hydrogen sulphide production, GLU = glucose test, $\mathrm{SUC}=$ sucrose test, LAC = lactose test, MRVP = Methyl red Voges-Proskauer test.

Table 4. Morphological and biochemical reactions of isolates.

\begin{tabular}{|c|c|c|c|c|c|}
\hline Isolates & PA & $\mathrm{CA}$ & CIT & IND & CAT \\
\hline E9 & + & + & + & + & + \\
\hline E11 & + & + & + & + & + \\
\hline E12 & + & + & - & + & + \\
\hline E13 & + & + & + & - & + \\
\hline E19 & + & + & + & + & + \\
\hline E20 & + & + & + & - & + \\
\hline E21 & + & + & + & - & + \\
\hline $\mathrm{E} 22$ & + & + & + & + & + \\
\hline
\end{tabular}

Key: PA: Pseudomonas isolation agar test, $\mathrm{CA}=$ coliform isolation agar test, $\mathrm{CAT}=$ catalase test, $-=$ negative,$+=$ positive, $\mathrm{IND}=$ indole test, $\mathrm{CIT}=$ citrate test.

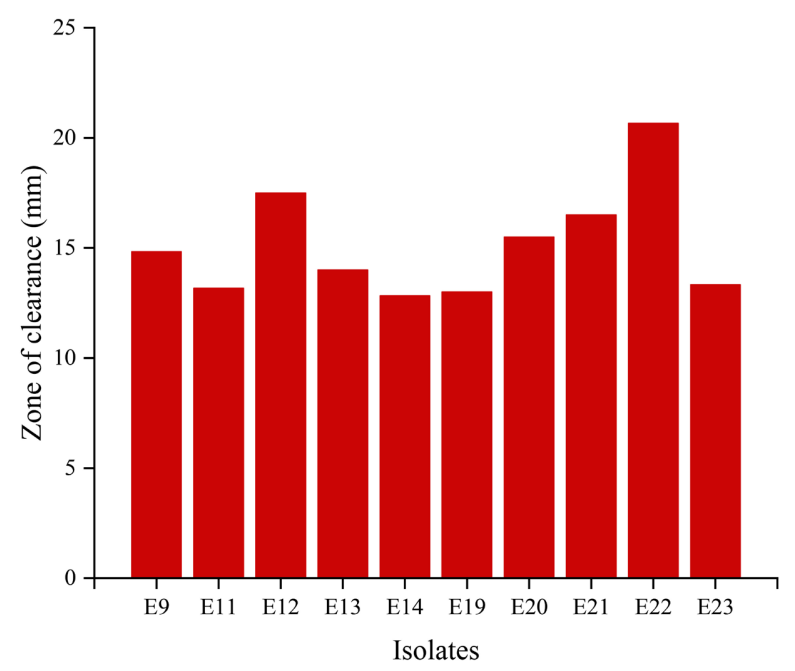

Figure 1. Zone of clearance of isolates upon methyl red utilisation for growth. 


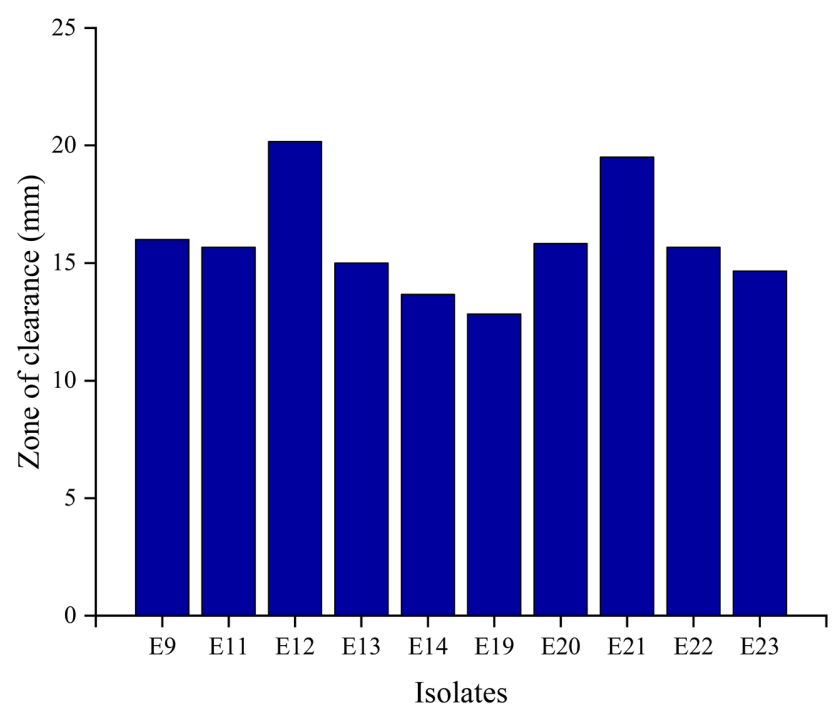

Figure 2. Zone of clearance of isolates upon methylene blue utilisation for growth.

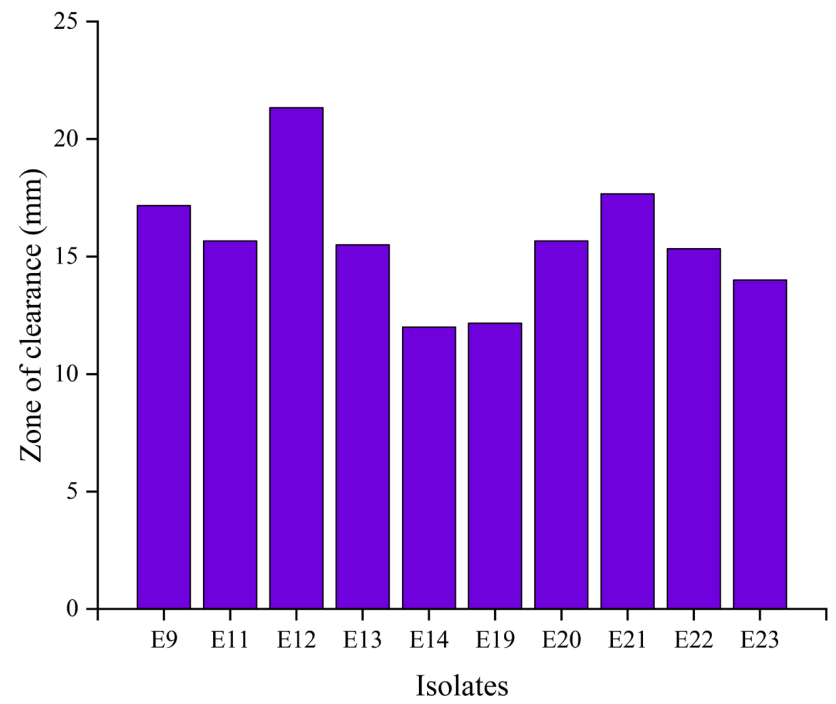

Figure 3. Zone of clearance of isolates upon crystal violet utilisation for growth.

\subsection{Decolourisation of Sample 6 (S6-VAT)}

From the dye decolourisation protocol with respect to sample 6 (S6), the parameter for measuring activity of the isolates was the degradation of dyes or "change in colour". The results from the HPLC analysis displayed different curves with their areas. Examples are shown in Figure 4 and Figure 5. The chromatogram obtained from the HPLC analysis demonstrated a wave profile confirming colour change. Each peak on the chromatogram represents a breakdown product of the original sample (S6). Similar study had been undertaken by [37].

However, in this study the area under the peaks were considered. The areas under the curve for the products after the microbial breakdown were smaller 


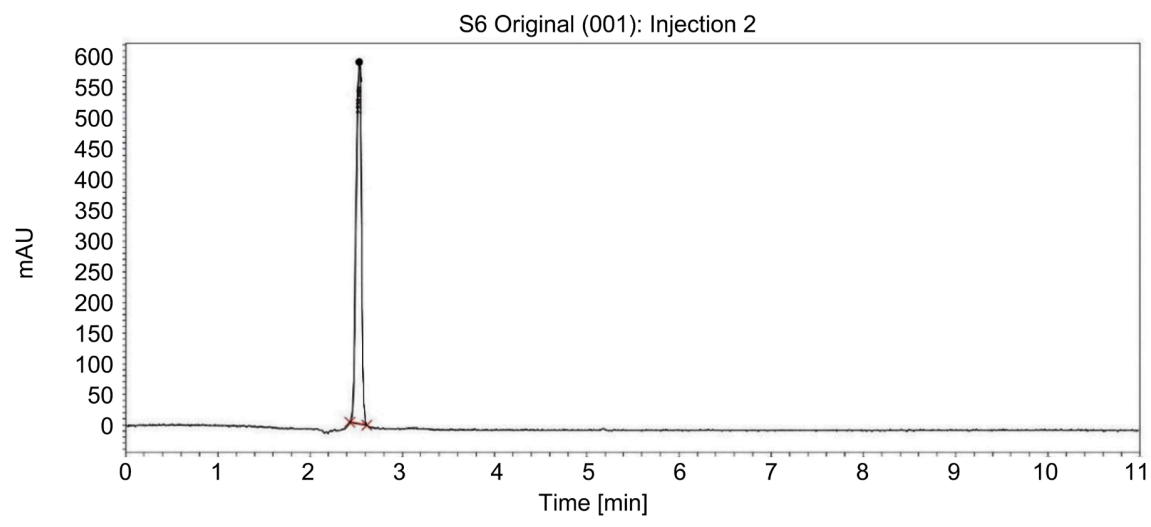

\begin{tabular}{|c|c|c|c|c|c|c|c|}
\hline Peak \# & $\mathrm{RT}(\min )$ & Component Name & Area & Height & $\mathrm{BL}$ & Final Amount & Units \\
\hline 1 & 2.536 & & $2,400,723.4$ & $590,877.6$ & $\mathrm{BB}$ & & \\
\hline Total & & & $2,400,723.4$ & & & & \\
\hline
\end{tabular}

Figure 4. HPLC chromatogram for original sample (without isolates).

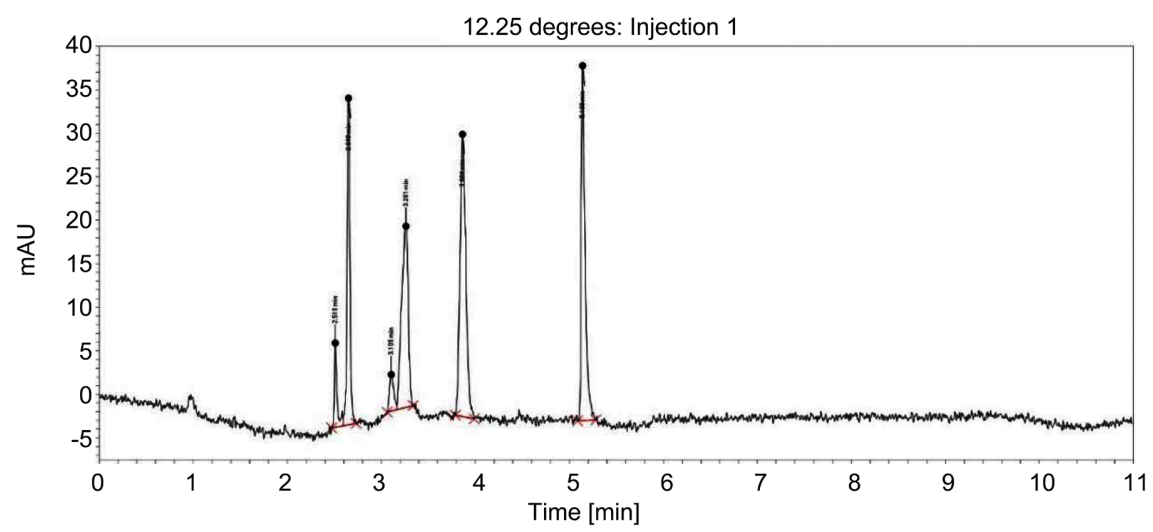

\begin{tabular}{|c|c|c|c|c|c|c|c|}
\hline Peak \# & $\mathrm{RT}(\min )$ & Component Name & Area & Height & $\mathrm{BL}$ & Final Amount & Units \\
\hline 1 & 2.510 & & $18,974.8$ & $9,598.5$ & BV & & \\
\hline 2 & 2.649 & & $78,701.8$ & $38,028.2$ & VB & & \\
\hline 3 & 3.105 & & $13,367.3$ & $4,197.0$ & BV & & \\
\hline 4 & 3.261 & & $103,738.6$ & $20,863.9$ & VB & & \\
\hline 5 & 3.864 & & $139,818.5$ & $32,440.2$ & $\mathrm{BB}$ & & \\
\hline 6 & 5.139 & & $113,771.7$ & $41,182.0$ & $\mathrm{BB}$ & & \\
\hline Total & & & $468,372.7$ & & & & \\
\hline
\end{tabular}

Figure 5. HPLC chromatogram for sample inoculated with isolate E12.

compared to the peak of the original sample. It could be inferred from Beer's law that, the area under each curve is directly proportional to the concentration of the compound in the sample. Hence, a decrease in the area of the curve means a decrease in the concentration of these compounds by the action of the isolates. Figure 6 and Figure 7 represent the differences between the original sample and the total area under the curve of each isolate at $25^{\circ} \mathrm{C}$ and $40^{\circ} \mathrm{C}$ after decolourisa- 
tion for 24 hours. The decolourisation process was carried out at the two temperatures of $25^{\circ} \mathrm{C}$ and $40^{\circ} \mathrm{C}$ in order to ascertain the better working temperature of the isolates. The isolates performed better at $25^{\circ} \mathrm{C}$ than at $40^{\circ} \mathrm{C}$ as shown in Figure 6 and Figure 7. The $\mathrm{pH}$ values after decolourisation ranged from 7.43 7.82 at $25^{\circ} \mathrm{C}$ and $7.54-7.98$ at $40^{\circ} \mathrm{C}$ as presented in Table 5. The $\mathrm{pH}$ had dropped from 8.25 to these ranges.

Decolourisation at $25^{\circ} \mathrm{C}$

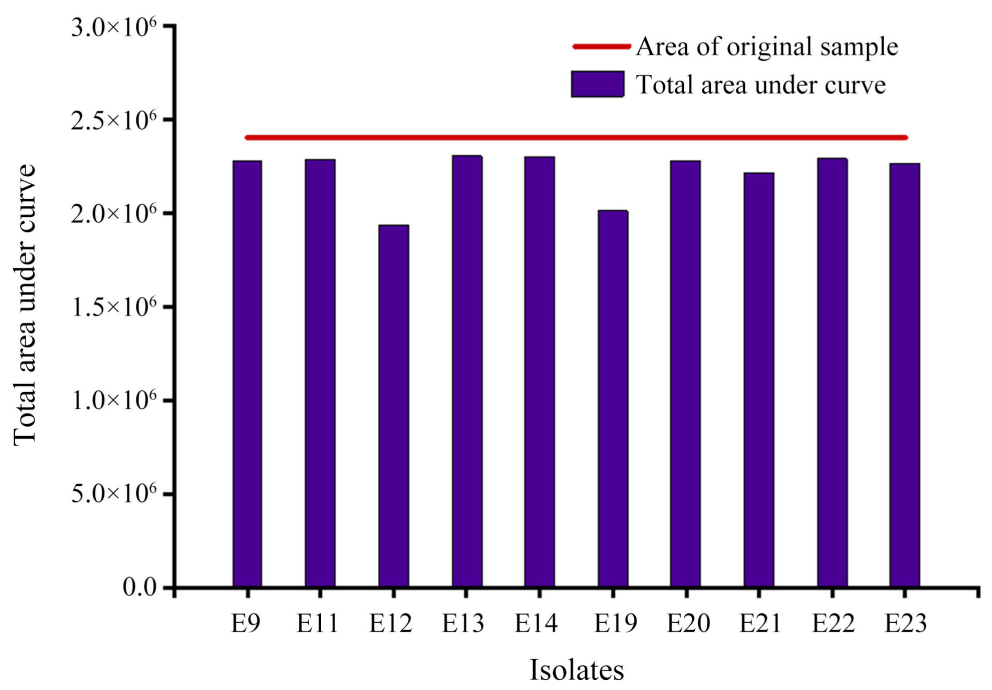

Figure 6. Total area of sample with isolates and the original sample at $25^{\circ} \mathrm{C}$.

Decolourisation at $40^{\circ} \mathrm{C}$

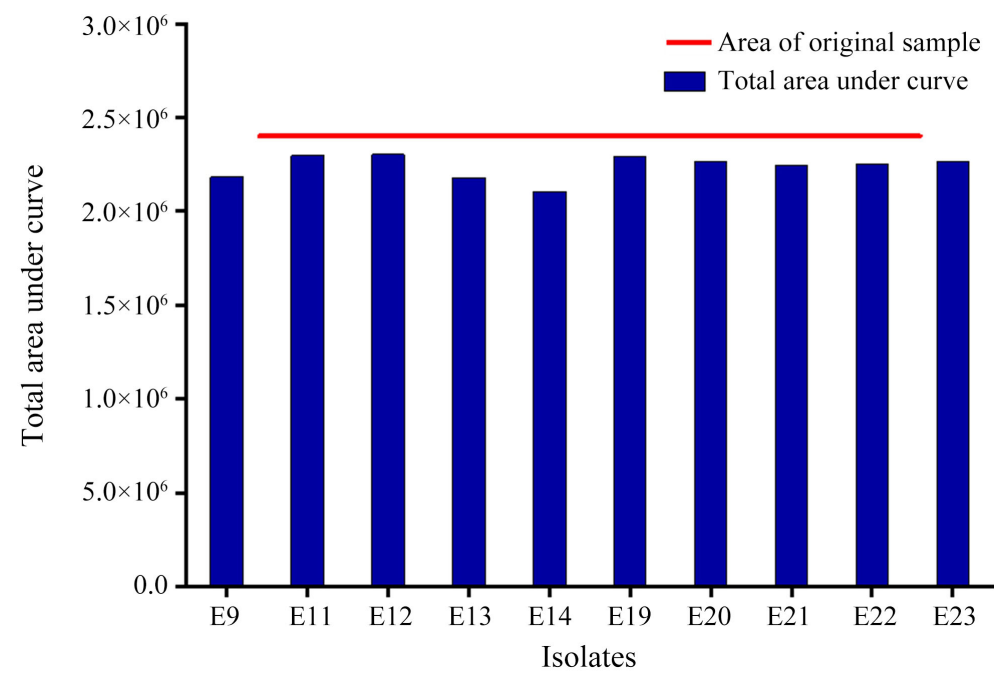

Figure 7. Total area of sample with isolates and the original sample at $40^{\circ} \mathrm{C}$.

Table 5. The $\mathrm{pH}$ results after decolourisation of sample 6 at $25^{\circ} \mathrm{C}$ and $40^{\circ} \mathrm{C}$.

\begin{tabular}{cccccccccccc}
\hline Samples with Isolates & E9 & E11 & E12 & E13 & E14 & E19 & E20 & E21 & E22 & E23 \\
\hline pH at $25^{\circ} \mathrm{C}$ & 7.62 & 7.43 & 7.45 & 7.82 & 7.68 & 7.63 & 7.80 & 7.68 & 7.45 & 7.80 \\
pH at $40^{\circ} \mathrm{C}$ & 7.57 & 7.98 & 7.61 & 7.88 & 7.85 & 7.58 & 7.91 & 7.54 & 7.84 & 7.92 \\
\hline
\end{tabular}


Based on these findings, five isolates that exhibited better decolourisation potentials were further selected for the decolourisation of sample 7 (S7). Change in colour was observed using the UV-vis spectrophotometer. These are isolates E9, E12, E19, E21 and E23.

\subsection{Decolourisation of Sample 7 (S7-R0 Reject)}

The extent of decolourisation was determined by measuring the absorbance (at $\lambda \max =251 \mathrm{~nm}$ ) of the samples at a 2 hour-interval (for 12 hours) except the last observation which was taken after 24 hours of inoculation (i.e. 0, 2, 4, 6, 8, 10, 12 and 24). Isolate E12 demonstrated a remarkable absorbance profile depicting a reduction in concentration as compared to the activity of the isolates, E9, E21, E23 and E19, as presented in Table 6. The decolourisation efficiency was calculated according to the formula given by [26].

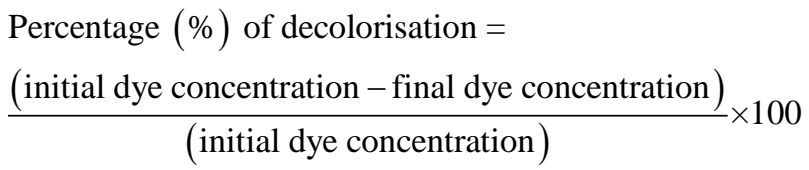

After 24 hours, the decolourisation efficiencies of the 5 isolates were calculated. Decolourisation of Sample 7 (S7) by the 5 isolates was recorded and the highest decolourisation efficiency $(78.5 \%)$ was observed with isolate E12. Isolate E23 recorded $64.7 \%$ followed by isolate E9 (62.0\%) and E21 (53.7\%) after 24 hours. Isolate E19 had the lowest decolourisation (2.6\%) after 24 hours. The decolourisation efficiencies from this study as shown in Figure 8, agree with the assertion of [6] [39] that, decolourisation of textile wastewater without complete dye degradation can be sufficient for reuse of water as long as the metabolites produced are well-characterised and display no environmental effect. $\mathrm{pH}$ values after decolourisation ranged from $7.84-8.73$ at $25^{\circ} \mathrm{C}$ as presented in Table 7. The $\mathrm{pH}$ had dropped from 9.12 to these ranges.

Analytical Profile Index (API) 20E test was conducted on the 5 selected isolates used in decolourising sample 7. The test confirmed that the microorganisms belong to the Aeromonas and the Pseudomonas genera. From the results (Table 8), isolate E9 was identified as Aeromonas hydrophilia, E21 as Aeromonas hydrophilia, E12 as Aeromonas hydrophilia, E23 as Pseudomonas fluorescen, and E19 as Pseudomonas aeruginosa.

[36] isolated a novel bacterial strain known as Aeromonas hydrophilia from a textile wastewater treatment plant. However, the decolourisation abilities of these isolates were measured using only individual triarylmethane dyes with an average decolourisation efficiency of $75 \%$. However, the findings obtained from this study demonstrated a higher decolourisation efficiency of $78 \%$. Also the Aeromonas hydrophilia strain was able to act on various dye effluents within 24 hours. [40] reported similar decolourisation potential of Aeromonas hydrophilia. The results of this study were consistent with their findings. This research also proved a better decolourisation efficiency (62.0\%) than the nonadapted Pseudomonas sp. (41.73\%) investigated by [37]. 
Table 6. Absorbance values recorded for each isolate after decolourisation of sample 7.

\begin{tabular}{cccccc}
\hline Time of Decolourisation & E9 & E21 & E23 & E12 & E19 \\
\hline 0 & 0.811 & 0.741 & 0.714 & 0.709 & 0.704 \\
2 & 0.630 & 0.610 & 0.596 & 0.639 & 0.699 \\
4 & 0.608 & 0.648 & 0.626 & 0.558 & 0.618 \\
6 & 0.608 & 0.575 & 0.565 & 0.593 & 0.635 \\
8 & 0.551 & 0.560 & 0.554 & 0.551 & 0.608 \\
10 & 0.550 & 0.543 & 0.582 & 0.548 & 0.546 \\
12 & 0.515 & 0.543 & 0.477 & 0.428 & 0.698 \\
\hline
\end{tabular}

Table 7. $\mathrm{pH}$ results after decolourisation of sample 7 at $25^{\circ} \mathrm{C}$.

\begin{tabular}{cccccc}
\hline Samples with isolates & E9 & E21 & E23 & E12 & E19 \\
\hline pH at $25^{\circ} \mathrm{C}$ & 7.91 & 8.10 & 7.93 & 7.84 & 8.73 \\
\hline
\end{tabular}

Table 8. Results for the API 20 E test.

\begin{tabular}{cl}
\hline Isolates & \multicolumn{1}{c}{ Identity } \\
\hline E9 & Aeromonas hydrophilia, \\
E12 & Aeromonas hydrophilia, \\
E19 & Pseudomonas aeruginosa \\
E21 & Aeromonas hydrophilia, \\
E23 & Pseudomonas fluorescens \\
\hline
\end{tabular}

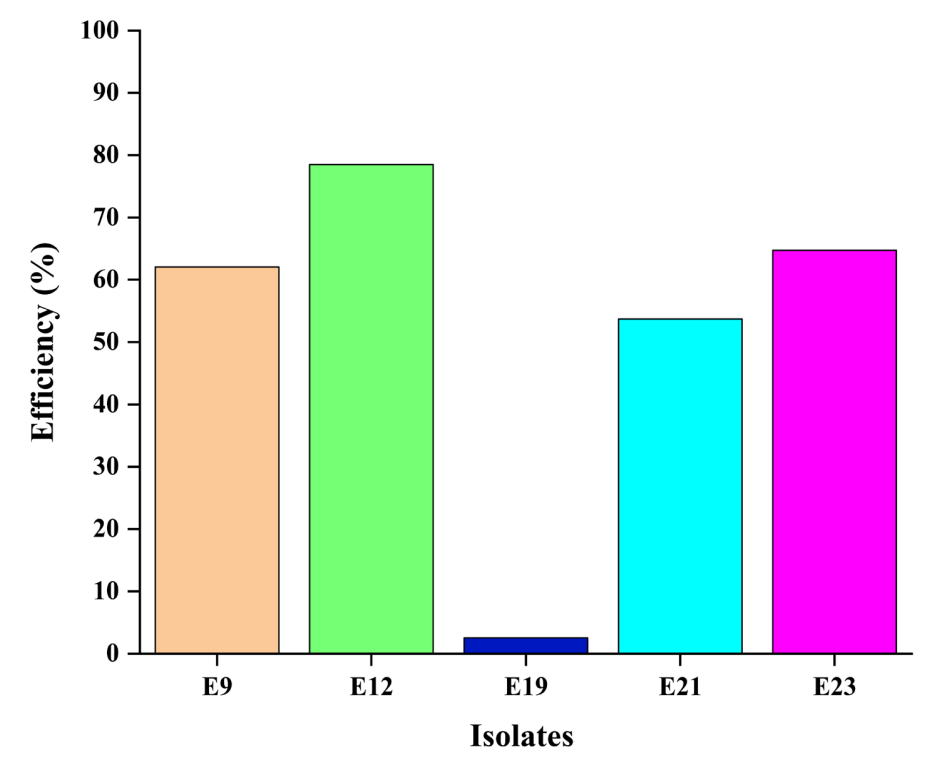

Figure 8. Decolourisation efficiencies of sample 7 by 5 isolates at the end of 24 hours.

Isolate E12 (Aeromonas hydrophilia) is thus, a good candidate for biological treatment of textile wastewater followed by isolate E23 (Pseudomonas fluorescens). 


\section{Conclusion}

Overall, in this study two promising strains of organisms belonging to the Aeromonas and Pseudomonas genera were identified as showing high potential for textile wastewater decolourisation. The microorganisms identified include Aeromonas hydrophilia and Pseudomonas fluorescens. To achieve a decolourisation efficiency of 78.5\%, $25 \mathrm{ml}$ of textile wastewater should be inoculated with $1 \mathrm{ml}$ of the isolate (E12) culture. Thus, Isolate E12 (Aeromonas hydrophilia) is considered a promising candidate for biological textile wastewater treatment followed by isolate E23 (Pseudomonas fluorescens). Interestingly, the bacterial species used in this research were isolated from the textile industry waste effluent. To remediate textile effluent efficiently and cost-effectively, further studies on genetic improvement and hybrids of the most effective strains should be carried out. Also potential health risks of these microorganisms and influence of process parameters on decolourisation should be studied.

\section{Conflicts of Interest}

The authors declare no conflicts of interest regarding the publication of this paper.

\section{References}

[1] El-Kassas, H.Y. and Mohamed, L.A. (2014) Bioremediation of the Textile Waste Effluent by Chlorella vulgaris. Egyptian Journal of Aquatic Research, 40, 301-308. https://doi.org/10.1016/j.ejar.2014.08.003

[2] Bhatia, D., Sharma, N.R., Singh, J. and Kanwar, R.S. (2017) Biological Methods for Textile Dye Removal from Wastewater: A Review. Critical Reviews in Environmental Science and Technology, 47, 1836-1876. https://doi.org/10.1080/10643389.2017.1393263

[3] Yagub, M.T., Sen, T.K., Afroze, S. and Ang, H.M. (2014) Dye and Its Removal from Aqueous Solution by Adsorption: A Review. Advances in Colloid and Interface Science, 209, 172-184. https://doi.org/10.1016/j.cis.2014.04.002

[4] Bhatia, D., Sharma, N.R., Kanwar, R. and Singh, J. (2018) Physicochemical Assessment of Industrial Textile Effluents of Punjab (India). Applied Water Science, 8, 83. https://doi.org/10.1007/s13201-018-0728-4

[5] Drumond Chequer, F.M., de Oliveira, G.A.R., Anastacio Ferraz, E.R., Carvalho, J., Boldrin Zanoni, M.V. and de Oliveir, D.P. (2013) Textile Dyes: Dyeing Process and Environmental Impact. In: Eco-Friendly Textile Dyeing and Finishing, InTech, London. https://doi.org/10.5772/53659

[6] Meerbergen, K., Willems, K.A., Dewil, R., Van Impe, J., Appels, L. and Lievens, B. (2018) Isolation and Screening of Bacterial Isolates from Wastewater Treatment Plants to Decolorize Azo Dyes. Journal of Bioscience and Bioengineering, 125, 448-456. https://doi.org/10.1016/j.jbiosc.2017.11.008

[7] Ratna, P.B.S. (2012) Pollution Due to Synthetic Dyes Toxicity \& Carcinogenicity Studies and Remediation. International Journal of Environmental Science, 3, 940 955.

[8] Katheresan, V., Kansedo, J. and Lau, S.Y. (2018) Efficiency of Various Recent Wastewater Dye Removal Methods: A Review. Journal of Environmental Chemical Engi- 
neering, 6, 4676-4697. https://doi.org/10.1016/j.jece.2018.06.060

[9] Dellamatrice, P.M., Silva-Stenico, M.E., de Moraes, L.A.B., Fiore, M.F. and Monteiro, R.T.R. (2017) Degradation of Textile Dyes by Cyanobacteria. Brazilian Journal of Microbiology, 48, 25-31. https://doi.org/10.1016/j.bjm.2016.09.012

[10] Kant, R. (2012) Textile Dyeing Industry an Environmental Hazard. Natural Sciences, 4, 22-26. https://doi.org/10.4236/ns.2012.41004

[11] Morshed Ahmed, M., Abdullah Al Masud, H.M., Rayhan Mahbub, K., Siddique Hossain, M., Zobaidul Alam, M. and Abul Manchur, M. (2015) Biodecolourization of Textile Dyes by Effluent Adapted Bacteria. IOSR Journal of Pharmacy and Biological Sciences, 10, 88-95.

[12] Guerra, E., Llompart, M. and Garcia-Jares, C. (2018) Analysis of Dyes in Cosmetics: Challenges and Recent Developments. Cosmetics, 5, 47.

https://doi.org/10.3390/cosmetics5030047

[13] Samchetshabam, G., Ajmal, H. and Choudhury, T.G. (2016) Impact of Textile Dyes Waste on Aquatic Environments and Its Treatment. Environment and Ecology, 35, 2349-2353. https://www.researchgate.net/publication/321443064

[14] Si, L., Wei, Y., Chenglong, C., Yanbo, W. and Shuangchun, Y. (2013) Research Progress of the Physical and Chemical Treatment of Dye Wastewater. International Journal of Scientific \& Engineering Research, 4, 2010-2012.

https://www.ijser.org/researchpaper/Research-progress-of-the-physical-and-chemic al-treatment-of-dye-wastewater.pdf

[15] Mukherjee, D., Singh, S., Kumar, M., Kumar, V., Datta, S. and Dhanjal, D.S. (2018) Fungal Biotechnology: Role and Aspects. In: Fungi and Their Role in Sustainable Development: Current Perspectives, Springer, Singapore, 91-103. https://doi.org/10.1007/978-981-13-0393-7 6

[16] Lalnunhlimi, S. and Veenagayathri, K. (2016) Decolorization of Azo Dyes (Direct Blue 151 and Direct Red 31) by Moderately Alkaliphilic Bacterial Consortium. Brazilian Journal of Microbiology, 47, 39-46. https://doi.org/10.1016/j.bjm.2015.11.013

[17] Singh, R.L., Singh, P.K. and Singh, R.P. (2015) Enzymatic Decolorization and Degradation of Azo Dyes-A Review. International Biodeterioration \& Biodegradation, 104, 21-31. https://doi.org/10.1016/j.ibiod.2015.04.027

[18] Hassaan, M., El Nemr, A. and Hassaan, M.A. (2017) Health and Environmental Impacts of Dyes: Mini Review. American Journal of Environmental Science and Engineering, 1, 64-67.

[19] Joshi, P.A., Jaybhaye, S. and Mhatre, K. (2015) Biodegradation of Dyes Using Consortium of Bacterial Strains Isolated from Textile Effluent.

https://www.imedpub.com/articles/biodegradation-of-dyes-using-consortium-of-ba cterial-strains-isolated-from-textile-effluent.pdf

[20] Warade, A.R., Gaikwad, R.W., Sapkal, R.S. and Sapkal, V.S. (n.d.) Study of Removal Techniques for Dyes by Adsorption: A Review.

http://ijariie.com/AdminUploadPdf/STUDY OF REMOVAL TECHNIQUES FO R DYES BY ADSORPTION A REVIEW ijariie2687.pdf

[21] Akter, K., Zerin, T. and Banik, A. (2020) Biodegradation of Textile Dyes by Bacteria Isolated from Textile Industry Effluents. Stamford Journal of Microbiology, 9, 5-8. https://doi.org/10.3329/sjm.v9i1.45649

[22] Rahman, S.S., Alif, F.A. and Hossain, M.M. (2018) Retracted: Optimization of Conditions for the Biological Treatment of Textile Dyes Using Isolated Soil Bacteria [Version 1; Peer Review: Retracted]. F1000Research, 7, 351.

https://doi.org/10.12688/f1000research.15324.1 
[23] Vikrant, K., Giri, B.S., Raza, N., Roy, K., Kim, K.H., Rai, B.N. and Singh, R.S. (2018) Recent Advancements in Bioremediation of Dye: Current Status and Challenges. Bioresource Technology, 253, 355-367. https://doi.org/10.1016/j.biortech.2018.01.029

[24] Sultana, B. (n.d.) Degradation of Dyes Used in Textile Industries by Bacteria Isolated from Local Textile Effluents. Fulfilment of the Requirements for the Degree of Master of Science in Biotechnology. BRAC University, Dhaka.

[25] Srinivasan, G.P., et al. (2014) Biodegradation of Carcinogenic Textile Azo Dyes Using Bacterial Isolates of Mangrove Sediment. Journal of Coastal Life Medicine, 2, 154-162.

[26] Karim, M.E., Dhar, K. and Hossain, M.T. (2018) Decolorization of Textile Reactive Dyes by Bacterial Monoculture and Consortium Screened from Textile Dyeing Effluent. Journal of Genetic Engineering and Biotechnology, 16, 375-380. https://doi.org/10.1016/j.jgeb.2018.02.005

[27] Zabłocka-Godlewska, E., Przystaå, W. and Grabińska-Sota, E. (2014) Decolourisation of Different Dyes by Two Pseudomonas Strains under Various Growth Conditions. Water, Air, \& Soil Pollution, 225, 1846-1859.

https://doi.org/10.1007/s11270-013-1846-0

[28] Roy, D.C., Biswas, S.K., Saha, A.K., Sikdar, B., Rahman, M., Roy, A.K., Prodhan, Z.H. and Tang, S.S. (2018) Biodegradation of Crystal Violet Dye by Bacteria Isolated from Textile Industry Effluents. PeerJ, 72, e5015. https://doi.org/10.7717/peerj.5015

[29] Boateng, D. (n.d.) Hydrocarbon Degrading Microbes in Some Selected Engine Oil Polluted Sites in the Kumasi Metropolis. Kwame Nkrumah University of Science and Technology, Kabwe.

[30] Case, C.L., Tortora, G.J. and Funke, B.R. (2010) Microbiology, an Introduction. Tenth Edition. Pearson Education Inc., San Francisco.

[31] Sultana, B. (2017) Degradation of Dyes Used in Textile Industries by Bacteria Isolated from Local Textile Effluents. BRAC University, Dhaka.

[32] Marimuthu, T., Rajendran, S. and Manivannan, M. (2013) A Review on Bacterial Degradation of Textile Dyes. Journal of Chemistry and Chemical Sciences, 3, 201212.

[33] Srivastava, S. and Khan, K.A. (2014) Decolorization and Degradation of Textile Dyes by Bacterial Isolates. Research in Environment and Life Sciences, 7, 299-304. https://www.researchgate.net/publication/266153808 Decolorization and degradat ion of textile dyes by bacterial Isolates

[34] Martinez-Urtaza, J., Lozano-Leon, A., Viña-Feas, A., De Novoa, J. and Garcia-Martin, O. (2006) Differences in the API 20E Biochemical Patterns of Clinical and Environmental Vibrio parahaemolyticus Isolates. FEMS Microbiology Letters, 255, 75-81. https://doi.org/10.1111/j.1574-6968.2005.00052.x

[35] Guadie, A., Tizazu, S., Melese, M., Guo, W., Ngo, H.H. and Xia, S. (2017) Biodecolorization of Textile Azo Dye Using Bacillus sp. Strain CH12 Isolated from Alkaline Lake. Biotechnology Reports, 15, 92-100. https://doi.org/10.1016/j.btre.2017.06.007

[36] Ogugbue, C.J. and Sawidis, T. (2011) Bioremediation and Detoxification of Synthetic Wastewater Containing Triarylmethane Dyes by Aeromonas hydrophila Isolated from Industrial Effluent. Biotechnology Research International, 2011, Article ID: 967925. https://doi.org/10.4061/2011/967925

[37] Leena, R. and Raj, S. (2008) Bio-Decolourization of Textile Effluent Containing Reactive Black-B by Effluent-Adapted and Non-Adapted Bacteria. African Journal of Biotechnology, 7, 3309-3313. 
https://www.researchgate.net/publication/286292485 Bio\%20decolourization of te xtile effluent containing Reactive Black-B by effluent-adapted and non-adapted bacteria

[38] Alalewi, A. and Jiang, C. (2012) Bacterial Influence on Textile Wastewater Decolorization. Journal of Environmental Protection (Irvine, Calif.), 3, 889-903. https://doi.org/10.4236/jep.2012.328104

[39] Meerbergen, K. (2018) Decolorization of Textile Wastewater, with an Emphasis on Microbial Treatment Processes. PhD Thesis, KU Leuven, Science, Engineering \& Technology, Leuven.

[40] El Bouraie, M. and El Din, W.S. (2016) Biodegradation of Reactive Black 5 by Aeromonas hydrophila Strain Isolated from Dye-Contaminated Textile Wastewater. Sus tainable Environment Research, 26, 209-216.

https://doi.org/10.1016/j.serj.2016.04.014 